\title{
Constitutional Accords and National Discord: The Impact of Constitutional Reform on Canadian Unity
}

ERIC SNOW

Two particularly significant efforts have been made to amend the constitution since it was patriated in 1982: the Meech Lake Accord and the Charlottetown Accord. During each process, Canadian leaders acted boldly and decisively to renew Canadian federalism, satisfy the disenfranchised and keep all Canadians happy at once. However, while constitutions are intended to draw people together under a common purpose, this bold action succeeded in nothing but driving Canadians apart. The country was politically fractured into a collection of divided constituencies, and at its culmination the country was almost torn apart forever. Starting with the aftermath of the Constitution Act, 1982, this paper will consider several proposals from the Meech Lake and Charlottetown Accords respectively. The reasons why each accord failed will be considered in turn, as well as the consequences of that failure. Finally, there will be a 
consideration of approaches to renewing Canadian federalism that have occurred since the failure of the Accords. This will demonstrate that major constitutional reform has wrought only negative consequences on national unity; non-constitutional approaches, despite their limitations, serve as a more feasible and practical method of renewing Canadian federalism.

The Liberal government under Pierre Trudeau was successful in patriating the constitution through Constitutional Act, 1982. However, while the Act gained the support of nine of the ten provinces, Quebec remained a solitary holdout. Though the consent of Quebec was unnecessary for approval, as there was no amending formula at the time, in 1981 the Quebec National Assembly passed a decree rejecting the Act. A number of nationalists who had campaigned on the "Yes" side in the 1980 referendum on sovereignty joined Brian Mulroney's Progressive Conservative Party, seeking to formally bringing Quebec into the constitution. Mulroney came to power in 1984, while the Quebec Liberal Party under Robert Bourassa was elected in 1985 over the sovereigntist Parti Québécois who had opposed the 1982 patriation. With these leaders in place, there was an interest on both sides in resolving the issue in a cooperative fashion. Presented with an opportunity to go beyond the successes Trudeau had achieved, Mulroney brought forward a new round of constitutional discussions. Whether or not the re-opening of the constitution was necessary remains unclear, particularly with the urgency with which it was done. Many of Quebec's concerns could be resolved without a constitutional approach, as was done more recently. Furthermore, Quebec's sovereigntist former government may well have rejected any proposal the federal government could have put forward in 1980, providing an understandable reason for Quebec's opposition. Even if Mulroney were successful, Quebec's support would be more symbolic than institutional.___ In spite of this, the negotiations began in 1986 when Bourassa released a list of five 
demands that would have to be satisfied to bring Quebec into the constitution. The demands consisted of recognition of Quebec as a distinct society, greater power in immigration, a role in the selection of Supreme Court justices, a veto on future constitutional change and limitations on federal spending power in provincial jurisdictions. ${ }^{1}$ These five demands were pivotal in the reopening of the constitution during the Meech Lake Accord, and they remained central points of discussion even after the constitutional efforts broke down.

The notion of recognizing of Quebec as a distinct society is at least as old as Canada itself. Section 94 of the constitution recognizes a distinction in laws relating to Property and Civil Rights based on the civil law tradition in Quebec. ${ }^{2}$ Nevertheless, of the five demands, the distinct society clause has been the greatest cause of

${ }^{1}$ Georges Matthews, Quiet Resolution: Quebec's Challenge to Canada, (Toronto: Summerhill Press Ltd, 1990), p. 84 2 Brian O'Neal, "Distinct Society: Origins, Interpretations, Implications", Social and Political Affairs Division, Parliamentary Research Branch, (December 1995), p. 4 controversy. Legally, this clause did not seem to have a clear or direct effect. Nevertheless there were some, including Pierre Trudeau, who argued that writing it in an interpretive clause instead of the preamble indicates an allocation of power to the government of the distinct society. ${ }^{3}$ Opposition to the distinct society clause grew more prominent after the Supreme Court struck down a Quebec law requiring French only signs as it was a violation of the Charter of Rights and Freedoms. In response, Bourassa reaffirmed the law using the notwithstanding clause, with only a minor alteration from the previous law that would allow the use of signs indoors. ${ }^{4}$ Though there was no direct link between the law and the Accord's distinct society clause, Bourassa's actions called into question the rights of individuals under the distinct society clause in the minds of English Canadians.

\footnotetext{
${ }^{3}$ Donald Johnson (Ed), With a Bang, Not a Whimper: Pierre Trudeau Speaks Out, (Toronto: Stoddart Publishing Co., 1988), p. 75

${ }^{4}$ Russell, Constitutional Odyssey, p. 145
} 
The distinct society clause was not the only barrier to the approval of Meech Lake. Over the course of the negotiations, it became apparent that Quebec was not the only group of Canadians who felt neglected by the constitutional process. The aboriginal community felt they had been unfairly excluded from the negotiating process. Elijah Harper, an Amerindian member of the Manitoba legislature, significantly raised the profile of aboriginal constitutional concerns when he single-handedly blocked the Accord from coming to a vote until the deadline for approval had passed.

When it became evident that the Accord would fail as a result, Premier Clyde Wells of Newfoundland, the only other holdout province, decided not to bring the matter to a vote. ${ }^{5}$ In the end, the Meech Lake Accord not only failed in its goal of placating Quebec, but opened further wounds with other Canadian constituencies.

While the Accord had failed, it had only failed narrowly and largely as a result of running out of time.

${ }^{5}$ Matthews, Quiet Resolution, p. 101 19
There was certainly support for its initiatives, though it had become apparent that Quebec would not be the only group to accommodate in any future constitutional reform. Furthermore, the bi-partisan Bélanger-Campeau Commission had called for a new referendum on sovereignty no later than $1992 .{ }^{6}$ As a result, the almost immediate reopening of the constitution may well have been inevitable. Mulroney responded to the report of the Commission by calling a national referendum for that year, and so the negotiations of the Charlottetown Accord began.

The Charlottetown Accord included much of what had been present in the Meech Lake Accord, and expanded on a number of points. The distinct society of Quebec was preserved within a broader "Canada clause", which also touched on Canadian values such as democracy and the rule of law as well as

\footnotetext{
${ }^{6}$ Thomas Courchene, "The Changing Nature of Quebec-Canada Relations: From the 1980 Referendum to the Summit of the Canadas", IRPP Working Paper Series, no. 2004-08, (September 2004), p. 5
} 
aboriginal rights. ${ }^{7}$ However, while the Meech Lake Accord had not touched on the matter of Senate reform beyond provincial consultation in the appointment of Senators, the Charlottetown provided for a comprehensive overhaul. This included reducing the number of Senators to 62 , consisting of six for each province and one for each of the territories. While Quebec was hesitant about this vision of the Senate, which would significantly reduce Quebec's representation in the upper house, they accepted it based on compromises. One of these compromises was that Quebec would be guaranteed at least $25 \%$ of the seats in the House of Commons. Given that Quebec currently holds less than $25 \%$ of the population, this clause would guarantee overrepresentation for what is already Canada's second largest province, independent of any future population shifts. 8 The importance of Quebec's

${ }^{7}$ Russell, Constitutional Odyssey, p. 281 8 The population of Quebec is 7.2 million, not far behind Ontario (11.4 million) and almost double British Columbia (3.9 million), the next largest province. Based support allowed Quebec to expand its demands for special treatment on a clause designed to promote equality among provinces. As a result, the positive implications of one area of the constitution were compromised by demands from an individual constituency.

The Charlottetown Accord was weighed down by its attempts to please all constituencies. In a single debate, the Accord was criticized for giving Ottawa too much power and also for decentralizing the country, for giving Quebec both too much and too little, and for both giving too much power to Indian chiefs while doing too little for aboriginals. ${ }^{9}$ The attempts to please everyone within the framework of the Charlottetown Accord caused people to see it only for its flaws, which were significant enough to call for its rejection. The concessions for Quebec were a particularly divisive

on the 2006 census, <http://www.statcan.gc.ca/> ${ }^{9}$ Jeffrey Simpson, "The Referendum and its Aftermath", in The Charlottetown Accord, the Referendum, and the Future of Canada, ed. Kenneth McRoberts \& Patrick Monahan, (Toronto: University of Toronto Press, 1993), p. 195 
issue; while Quebec felt they were not getting enough, English Canada felt Quebec was getting too much. ${ }^{10}$ As a result, individuals on both sides of issues came together to rejected the Accord, with the notion that a better deal would be possible once this one had been rejected. Despite the support of all of the federal, provincial and territorial first ministers, three of the federal parties, all but two provincial opposition parties and countless other organizations and constituencies, it was nevertheless rejected. ${ }^{11}$ Of the $75 \%$ of Canadians who came out to vote, $54 \%$ rejected the Accord and it failed in six of the ten provinces. ${ }^{12}$

The damage that the Charlottetown Accord wrought on national unity became evident shortly thereafter, and the political landscape changed dramatically. The 1993 federal election included the most

${ }^{10}$ Brooke Jeffrey, Strange Bedfellows, Trying Times: October 1992 and the Defeat of the Powerbrokers, (Toronto: Key Porter Books, 1993), p. 9 11 Jeffrey Simpson, "The Referendum and its Aftermath", p. 194

${ }^{12}$ Brooke Jeffrey, Strange Bedfellows, Trying Times, p. 1-2 crushing defeat of a political party in Canadian history, with the governing Progressive Conservatives being reduced from a majority government to a mere two seats. While the Liberals were able to form a majority government, for only the second time in Canadian history no single party held a majority of opposition seats. The fractured opposition included two regional parties, neither of which had before won seats in a general election. The Reform Party, with origins as a party of western protest with the slogan "The West Wants In", managed to secure 52 seats despite having previously been considered a fringe group. While the Reform Party did run candidates across Canada, with the exception of Quebec, it claimed seats almost exclusively in western Canada. ${ }^{13}$ Additionally, the newly formed separatist Bloc Québécois secured a majority of seats (54 out of 75) in Quebec in the first federal election in its existence. Frustrations in Quebec were expressed further when the Parti Québécois under

\footnotetext{
13 Courchene, "The Changing Nature of Quebec-Canada Relations", p. 6
} 
Jacques Parizeau formed a new

government in 1994. Parizeau ran

with the promise of immediately

bringing forward a second Quebec

referendum on sovereignty. Though

the "No" side eventually emerged

victorious, it was by a far narrower

margin, $50.6 \%$ to $49.4 \%$, than it had

been during the referendum of $1980 .{ }^{14}$

The crises of the Charlottetown

Accord and the Quebec referendum on sovereignty referendum had come to a close. However, the underlying problems that had brought about the constitutional talks in the first place were still no closer to being resolved. The constitution remained largely unchanged since the Constitution Act, 1982. Quebec had reaffirmed its place as a province within Canada in through the referendum, despite the strong showing in favour of sovereignty ${ }_{-}$, and Furthermore, the Clarity Act enacted in 2004 outlined more clear and strict conditions any future referenda would have to follow. ${ }^{15}$ Though the country was

14 Courchene, "The Changing Nature of Quebec-Canada Relations”, p. 7

15 Russell, Constitutional Odyssey, p. 246 experiencing widespread

constitutional fatigue,

had reaffirmed Quebe's place as a provinee within Canada, and the need to unite the country was as great as ever. A new approach would be necessary for any further efforts to renew the federation and bring Quebec into its framework.

Almost immediately after the failure of the 1995 referendum, the Liberal government under Jean Chrétien introduced a motion to recognize Quebec as a distinct society without the use of a constitutional amendment. Despite the uneasiness in English Canada surrounding the distinct society matter, Chrétien's motion makes it clear that the House of Commons should be "guided by this reality" and "guided in [its] conduct accordingly". However, the wording was chosen carefully, the motion emphasized that Quebec is a distinct society "within Canada" and identifies its "French-speaking majority, unique culture and civil law tradition" as justification for this recognition. ${ }^{16}$

${ }^{16}$ O’Neal, “Distinct Society", p. 21 
While the motion was decried by sovereigntists as too little, too late, ${ }^{17}$ the motion presented a formal recognition and pushed the matter out of the public mind for the moment.

Another motion the Liberals quickly brought forward touched upon the veto Quebec had sought regarding constitutional change. While following loosely in the footsteps of Accord negotiations, the Liberal legislation neither gave Quebec a sole veto nor required unanimity across Canada. Instead, the legislation added greater stipulations to the rule of seven provinces with $50 \%$ of the population. The approval of Quebec, Ontario, British Columbia and Alberta ${ }^{18}$ became necessary, as well as one of the other two Prairie Provinces and two Atlantic provinces constituting $50 \%$ of the population in both regions. ${ }^{19}$ Though this formula was

${ }^{17}$ Russell, Constitutional Odyssey, p. 236 18 While Alberta does not have an explicit veto, their current population so large that their support is necessary to secure $50 \%$ of the population in the Prairie Provinces, thereby giving Alberta a de facto veto. Based on the 2006 census, <http://www.statcan.gc.ca/> ${ }^{19}$ Russell, Constitutional Odyssey, p. 237 not quite as demanding as unanimity, it diminished the authority of the smaller provinces, most notably rendering the support or dissent of Prince Edward Island irrelevant in the amendment process. ${ }^{20}$ Furthermore, after the Charlottetown Accord, there is precedent that any major constitutional changes must be put to referendum, or else they will be democratically illegitimate. As a result, a majority of the vote in provinces comprising at least with $92 \%$ of the population will be necessary for future constitutional amendments. ${ }^{21}$ If constitutional fatigue and the fear of the fate of the Progressive Conservative Party had not been sufficient deterrents, the stringency of the new rules may well have taken major constitutional

20 The current population of Prince Edward Island is so small (about $6 \%$ of Atlantic Canada) that any other two Atlantic provinces can achieve $50 \%$ of the regional population without them. Additionally, there is no combination of four provinces where at least one does not hold a veto. This renders PEI's support unnecessary and their dissent meaningless. Based on the 2006 census, <http://www.statcan.gc.ca/>

${ }^{21}$ Russell, Constitutional Odyssey, p. 238 
reform off the table as a method of renewing the federation.

More recently, the Conservative government under Stephen Harper

has also committed to initiatives relating to federal spending power in provincial jurisdictions, including in the party's 2008 platform. Many of these initiatives are similar to those that were proposed under the Meech Lake and Charlottetown Accords. This includes requiring the consent of a majority of provinces for cost-shared programs and giving provinces the right to opt out provided they "offer a similar program with similar accountability structures". ${ }^{22}$

Interestingly, the language in Harper's approach is weaker than that of the Accords, which suggested programs would have to comply with "the national objectives," 23 which $\underline{\text { in }}$ turn had received criticism at the time for its weakness. This greater level of flexibility on the part of the federal

22 Conservative Party of Canada, The True North Strong and Free: Stephen Harper's Plan for Canadians, (October 7, 2008), <http://www.conservative.ca/media/200 81007-Platform-e.pdf>, p. 26

${ }^{23}$ Russell, Constitutional Odyssey, p. 287 government occurred without a negotiating process with the provincial governments.

Despite the efforts of successive governments, some constitutionrelated reforms have been no more successful through non-constitutional approaches than they were through constitutional ones. Senate reform, a key plank of the modern Conservative platform, continues to be largely unsuccessful as it has been for the past thirty to forty years. There have been at least twenty different proposals and attempts at Senate reform, yet all of them have failed. ${ }^{24}$ Much of what Senate reform hoped to accomplish, including changes to its composition or powers, is impossible without a direct constitutional amendment. However, other areas can be dealt with, as the Harper Conservative government has attempted to do. Keeping Senators out of cabinet can be tackled by

24 Serge Joyal, Introduction of Protecting Canadian Democracy: The Senate You Never Knew, (McGill-Queen's University Press, 2003), <http://www.sen.parl.gc.ca/sjoyal/Joyal $\% 27 \mathrm{~s} \% 20$ book\%20docs/Introduction $\% 2$ 0 (Eng).htm> 
convention. Consultation with the provinces regarding their selection can easily be done; technically, this is how the process still works in regard to the Prime Minister and the GovernorGeneral. This process could even provide for the election of Senators by either or the provincial legislatures, or by popular vote as the Conservatives have proposed. The Harper government also included the introduction of fixed terms of no longer than eight years and new ethics rules in their 2008 platform. ${ }^{25}$

There are downsides to dealing to using non-constitutional approaches such as legislation or convention as a manner of renewing federalism. Any such legislation or convention is not constitutionally entrenched. As a result, the continuation of that process would depend on convention that could be ignored and legislation that can be overturned by future parliaments. While such policies would thereby lack permanence, this also serves as one of the benefits of a non-constitutional approach. Unlike

25 Conservative Party of Canada, The True North Strong and Free, p. 24 constitutional amendments, which have gone from difficult to almost impossible to achieve, these approaches can be improved upon or reconsidered if they no longer serve the national will. Furthermore, this process is made accountable through the democratic process. While such approaches could be achieved without consulting provincial governments, there would be a resulting backlash. The political ramifications also make the removal of previous legislation or convention unlikely, unless it is contrary to the democratic will.

Canada's self-imposed limitations on many types of constitutional amendments have increased since the constitution was patriated. The formula now requires virtual unanimity amongst the provinces and informally includes the expectation of a national referendum. For better or worse, a major constitutional overhaul in the spirit of the Meech Lake and Charlottetown Accords may now be impossible. The energy and enthusiasm surrounding changes to the constitution are far greater than that of any mere 
legislation, and this energy was at first harnessed to consider the possibilities for improvements and renewal. However, that same energy can be turned against the process once individuals perceive the amendments to be taking away their own rights, or favouring those of someone else.

During the Meech Lake and

Charlottetown Accords, this mentality caused a fight over Canadian differences, rather then the commonalities for which a constitution is formed and intended to reflect. In the words of Machiavelli, "there is nothing more difficult to arrange, more doubtful of success, and more dangerous to carry through than initiating change to a State's constitution". Efforts to renew the federation are meaningless if they come at the cost of the federation itself.

\section{Works Cited}

Conservative Party of Canada. The True North Strong and Free: Stephen Harper's Plan for Canadians. October 7, 2008. $<$ http://www.conservative.ca/media/20081007-Platform-e.pdf $>$

Courchene, Thomas. "The Changing Nature of Quebec-Canada Relations: From the 1980 Referendum to the Summit of the Canadas". IRPP Working Paper Series, no. 2004-08. September 2004.

Jeffrey, Brooke. Strange Bedfellows, Trying Times: October 1992 and the Defeat of the Powerbrokers. Toronto: Key Porter Books, 1993.

Johnson, Donald (ed.). With a Bang, Not a Whimper: Pierre Trudeau Speaks Out. Toronto: Stoddart Publishing Co., 1988.

Joyal, Serge. Introduction of Protecting Canadian Democracy: The Senate You Never Knew. McGill-Queen's University Press, 2003.

Matthews, Georges. Quiet Resolution: Quebec's Challenge to Canada. Toronto: Summerhill Press Ltd, 1990. 
McRoberts, Kenneth and Patrick Monahan, ed. The Charlottetown Accord, the Referendum, and the Future of Canada. Toronto: University of Toronto Press, 1993.

O’Neal, Brian. "Distinct Society: Origins, Interpretations, Implications". Social and Political Affairs Division, Parliamentary Research Branch. December 1995.

Russell, Peter. Constitutional Odyssey: Can Canadians Become a Sovereign People?. Toronto: University of Toronto Press, 2004. 